Lizard rocks. They had been carried to Falmouth in a boat. To r rgain their home they had first to find therr way to the mouth of the harbour, and when there, how did they know whether to steer to the right or to the left, and to travel seven miles to their native rocks?

Another, of which the drover is my informant. Large flocks of sheep are ciriven weekly from the Welsh hills to the London market. Some time since two escaped in the dark and were supposed to have been stulen. About a fortnight afterwards the two stray sheep reappeared on the Welsh mountains, whence they had been brought. They had found therr way through a journey of at least Ioo miles. My informant learned from some of the turnpike-gate keep-rs on the road that, when opening the gate at night to a traveller, two sheep had been seen to rush through.

The nightingale returns from Greece, not merely to the same country, but to the same field and the self-same bush. The swallow takes possession of the same nest.

Carlton Club, March $3 \mathbf{I}$ EDWARD W. Cox, Serjeant-at-law

\section{The Sociability of Cats}

IT may prove of interest to naturalists to record the following curious instance of the so ial habits of cats:-

I once had two she cais that were upon very intimate terms with each other, always together, and never appeared to have quarrelled. At one time, one of them being about to add an increase to their number, the other very kindly nursed it, and even performed the function of a midwife, and actually attended to the necesary offices that aie in ordinary cases attended to by the parent of the progeny. Feeling some interest in curiosties of natural history, I carefully watched my pets, and can therefore vouch for the truthfulness of this extraordinary manifestation of feline sociability.

I may here mention that, as regards the teachableness of cats, I once saw at the house of an intimate friend a fine, large tabby tom-cat put through a diill which would perhaps outvie similar exhibitions of the genus homio. He was told to "stand up," "shoulder arms," "present arms," and "stand at ease," which, by observing the hands of the master, he would most obediently do, and with a promptness that was astounding. Another cat was told "to beg," which it at once did by jumping on to a Windsor chair, and performed some curious twistings and rollings that were continuer until the morsel of meat was awarded. I have recently miroduced a fine kitten to the company of two cats I have had for years. For a long time a deadly feeling of enmity was maintained against the stranger; but now, after a period of three months, the two older cats will not lap their morning's milk until the kitten is in their company; if absent, they actually retire, and refuse to take their meal.

Red Lion Street, March 26

J. JEREMIAH

\section{Manitoba Observatory}

Having seen in vol. vii. p. 289 of NATURE a statement to the effect that the American Government had established an observatory at Fort Garry, Manitoba, $I$ have to inform you that the so-called observatory is a telegraph reporting station maintained by the Dominion of Canada. Its tri-daily reports, however, in common with those from several other Canadian telegraph stations in correspondence with Toronto, are always placed at the disposal of the Washington weather office.

G. T. KINGSTON

Magnetic Observatory, Toronto, Canada, March II

\section{ST. THOMAS CHARTERHOUSE TEACHERS' SCIENCE CLASSES}

PRIOR to the introduction of Mr. Lowe's revised code, elementary science teaching was always to be found in the curriculum of our best primary schools. The properties of water, the constiturnts of some of the chemical elements, the first principles of mechanics and the like, were taught with much pleasure by the misters of the schools above alluded to "Pdyment by results" on the three R's threw cold water upon this class of intellectual teaching, and it has only been revived recently through agitation emanating from enlightened educators. Teachers of late years too have had their studies very much limited by the low requirements of the Education department, and hence many young teachers were launched out into the teacher's profession unable themselves to impart instruction formerly given in our schools. Teachers have long been clamorous for having the standard of education raised in their schools, and have therefore hailed with great satisfaction the act of the Science and Art Department whereby additional grants are given to any pupils or adults or juveniles who could, after receiving a certain number of lessons from a qualified teacher, pass an examination on the subjectmatter of these lectures. Teachers, however, before they are permitted to give these lectures to pupils, are required to pass an advanced examination on the subjects they propose to teach. To enable teachers to pass these tests, the St. Thomas Charterhouse Teachers' Classes were inaugurated in October last. The idea was organised by Mr. C. Smith, one of the teachers and organising secretaries, and was carried out under the auspices of the Rev. J. Rodgers, M.A. To the credit of our primary teachers it ought to be added that they have snce the promulgation of the idea wosked most heartily to bring it to this desired consun metion. Pro's. Huxley, Ansted, Carruthers, Sir John Bennett, and several otber scientific men joined the committee for carrying out the classes. From every part of London masters and mistresses of our elementary schools gl dly joined the Science School. Over 230 teachers were initiated, and it is hoped that most of the teachers will qualify themselves in the coming May examination to be able to teach the scien ce subjects they have studied in these classes. Thus from this nucleus it is thought that next year we shall have science classes in connection with nearly every school (elementary) in the metropolis; and undoubtedly in a year or two more the inculcation of elementary general science knowledge will be almost universal.

Science teaching in the hands of a skilful instructor is always popular with young people, and as elementary teachers are eminently successful as collective teachers of the young, who could be better entrusted with imparting irstruction which so brightens the inteliect as these educators? The chief subjects taken this year at this science school are chemistry, mathematics, acoustics, light and heat, magnetism and electricity, botany (systematic and economic), geology, physiology, plane and solid geometry; but next year the promoters of the scheme hope to have classes in all the twenty-five subjects recognised by the Science Department of the Government. Most of the present students of the classes go in vigorously for physiology, physical geography, and acoustics, light and heat, a great many for chemistry. The teacher of chemistry, Mr. Spratling, has got up a first-rate laboratory for chemical experiments. Mr. Payne, teacher of magnetism and electricity, has all the approved auxiliaries for performing experiments connected with this subject. Next year the biology students will have every facility afforded them for microscopical practice. Mr. Simpson, who has done at least as much as any other person in London to train science teachers, is engaged as the special lecturer on Biology.

During the present session several of our leading scientific men have given a professional lecture to stimulate the teachers in their studies. Dr. Gladstone, Dr. Jarvis, Prof. Ansted, Prof. Carruthers, Mr. Tylor, Rev. W. Panckridge, Prof. Skertchley amongst the number. All the ordinary lectures are given by elementary teachers who have qualified themselves to teach. Two of the students, Mr. Bird and Mr. Powell, who have spent some of their leisure moments in making observations in botanical science, render much valuable a:d to their fellow students in furnishing examples to lllustrate the lessons given in botany. The students generally are pursuing their studies with great avidity, and as was observed at the Devon Social Society Gathering, by Mr. C. Clarke the importance of these classes cannot be over-estimated 